EDITORIAL

\title{
A ACCOUNTABILITY NO CONTEXTO DA RESPONSABILIDADE FISCAL: A COMPREENSIBILIDADE DE SEUS INSTRUMENTOS
}

O termo accountability pode ser interpretado como sendo a responsabilidade que um ente adquire de prestar contas a outrem em decorrência da posição que ocupa em determinada organização. Pode ser concebido também como a consciência do dever de dar satisfações a terceiros por algo que se deve realizar. Nessa última acepção, estaríamos nos reportando à dimensão subjetiva da accountability, ou seja, à cobrança que a pessoa exerce sobre si própria quanto à necessidade de prestar contas a alguém.

No âmbito da gestão pública, o exercício da accountability implica prestar informações claras e confiáveis sobre diversos elementos, tais como eficiência com que se utilizam os recursos públicos, qualidade dos serviços prestados, cumprimento de metas, critérios de distribuição dos custos tributários e definição de prioridades. Como se pode observar, trata-se de um freio que a sociedade civil procura impor ao Estado no tocante à gestão dos recursos que lhe são fornecidos. Nesse sentido, accountability não deixa de ser também um mecanismo que pode contribuir para gerar vínculos de confiança entre governantes e governados.

A partir da Lei de Responsabilidade Fiscal, uma das questões que ganharam maior destaque no âmbito da Administração Pública é justamente a necessidade de dar total transparência à gestão. $\mathrm{O}$ que se pretende, nesse caso, é instrumentalizar os cidadãos para acompanhar a aplicação dos recursos públicos e verificar se os programas de governo contemplam as suas aspirações. Para viabilizar esse tipo de controle social, a Lei estabelece que se dê ampla divulgação a um conjunto de informações contidas nos seguintes documentos: planos, orçamentos e leis de diretrizes orçamentárias; relatórios de prestação de contas, relatórios da execução orçamentária e da gestão fiscal, entre outros. Ficou estabelecido, inclusive, que se utilizem meios eletrônicos de acesso público para promover uma maior disseminação das referidas informações.

Como não poderia deixar de ser, as informações de natureza contábil se transformaram em requisito de primeira ordem para viabilizar a consecução de tais objetivos. Afinal, nesse contexto, cabe à contabilidade dar a maior visibilidade possível às origens e aplicações dos recursos de que se vale o estado para cumprir o seu papel. Porém, em meio a tudo isso, há pelo menos uma questão que merece ser considerada. Ela diz respeito à compreensibilidade dos relatórios de que o estado se vale para prestar contas aos cidadãos. Será que, de fato, as informações contábeis se apresentam de forma compreensível ao cidadão comum?

Num país tão heterogêneo sob o ponto de vista socioeconômico, é recomendável que se verifique se efetivamente os cidadãos estão encontrando nesses relatórios informações que lhes permitam efetuar um julgamento adequado sobre a gestão pública. $O$ fato de se publicar este ou aquele documento não assegura a priori a desejada transparência fiscal. Muito pelo contrário, quando veiculados sob uma linguagem hermética e distanciada da capacidade de compreensão de seus destinatários é provável que eles suscitem mais dúvidas e desconfianças. $\mathrm{Na}$ melhor das hipóteses, todo o esforço de evidenciação ficaria reduzido a uma retórica sem conseqüências de ordem prática. Esse é um problema que precisa ser considerado se realmente desejamos seguir o exemplo de outros Estados Democráticos e as recomendações de organismos multilaterais, a exemplo da ONU e da OEA, no tocante à transparência da gestão fiscal.

Com a rápida expansão dos meios de comunicação, sobretudo a Internet, criou-se a falsa sensação de que basta descarregar todas as informações em veículos de massa para que o 
cidadão tome conhecimento das práticas adotadas pela administração pública. Atualmente, muitos órgãos se ufanam da possibilidade de disponibilizar seus relatórios de gestão para consulta em rede, em qualquer parte do planeta. Não há duvidas de que isso já representa um grande avanço em relação a épocas em que informações dessa natureza estavam restritas às páginas do Diário Oficial. Porém, com raras exceções, o que se vê é um enorme volume de dados muito proveitosos para indivíduos que se encontram em nível cultural mais elevado e pouco atraentes para as camadas populares.

Aliás, é grande o volume de estudos que comprovam a inconveniência de se utilizarem termos de maior complexidade em mensagens dirigidas a públicos não especializados. $\mathrm{Na}$ área contábil, diversos estudos comprovam que expressões excessivamente técnicas raramente conseguem despertar significados compatíveis com os pretendidos. Nesse caso, verifica-se que os usuários tendem a desprezar as informações ou acabam realizando julgamentos distorcidos a respeito dos fenômenos que elas tentam representar. Para evitar problemas desse tipo, geralmente recomenda-se ajustar à linguagem às características médias dos usuários, considerando-se alguns fatores, tais como o contexto sociocultural, o nível de escolaridade, crenças, experiências anteriores e outros referenciais cognitivos. Ou seja, é necessário considerar que as "mensagens contábeis" só adquirem significado dentro de um quadro de referência.

José Maria Dias Filho Professor Doutor da Faculdade de Ciências Contábeis da UFBA 